\title{
EnVironment And The Students' Motivation in Studying Indonesian as a Foreign Language at GoBali Program, the UNIVERSITY OF UDAYANA -BALI
}

\author{
Anak Agung Sagung Shanti Sari Dewi, Putu Weddha Savitri \\ English Department, Faculty of Humanities, The University of Udayana-Bali \\ $\underline{\text { sari_dewi@unud.ac.id, weddha_savitri@unud.ac.id }}$
}

\begin{abstract}
This study focuses on analysing the students'motivation for studying Indonesian as a foreign language at GoBali, a onesemester international study program at the University of Udayana, particularly investigating the students'motivation during the course and analysing how the environment influences their learning motivation. This study involved 76 foreign students and 4 instructors in four Indonesian Language classrooms at the program and the data were collected through survey technique, classroom observation and interview. The results show that the students' motivation in learning Bahasa Indonesia is varied and in general is relatively low. However, the environment where they study the language has actually given an advantage for the learning in which the students become more motivated to learn the language for their daily lives in Bali, apart from whether it will give further benefits for their future or not.
\end{abstract}

Keywords: Motivation, Foreign Students, Indonesian, Teaching, Learning

\section{INTRODUCTION}

There are many scholars that have addressed the importance of motivation in learning a foreign language. Zolan Dörnyei (2008) stated that motivation is indeed one of the determining factors of second/foreign language learning success. Similarly, Oroujlou \& Vahedi (2011) asserted that the variable postulates primary impulse to commence a language learning and "later the driving force to sustain the long and often tedious learning process" (p.1). Motivation derives from a Latin word movere mean "to move". It concerns the driving force which moves a person to achieve his goal; It is something that gets somebody going, keeps him working and completes tasks. Motivation gives influence to what, when and how a person does something. Gardner (2010) explains that when individuals have motivation, they will make efforts to attain their goal. Accordingly, they will "show persistence, attend to the tasks that are necessary to achieve the goals, have a strong desire to attain their goal, enjoy the activities necessary to achieve their goal, are arouse in seeking their goals, have expectancies about their success and failures." (in Pineda, 2011: 33). Motivation is, hence, a determining factor of second / foreign language (Dörnyei, 2004: 273).

This study focuses on the students'motivation for studying Indonesian as a foreign language at a one-semester international study programs named GoBali at the University of Udayana Bali Indonesia. The university is one of the Indonesia's leading universities and is the largest and most renowned university in Bali. It has one of the largest international student communities in Indonesia and offers several international study programs where Indonesian language courses are included in all program tracks. One of them is Go Bali. Located in one of the world most famous tourist destinations, Go Bali intentionally designs the program in such a way to balance study time and spare time in combination, that is three study days in campus and four days off. Besides having been successful to attract more and more foreign students to study there, this design, then, has been bringing about a challenge to the management and to the lecturers, especially to those who teach Indonesian language: how to motivate the students to keep studying while they are enjoying holidays in Bali.

In order to solve the above problem, this study was conducted with the aims are to investig ate the students'motivation in learning Indonesian language at GoBali program, The University of Udayana, and to analyze how the environment influences their learning motivation. The goal is to attain a better understanding of students' motivation in Indonesian language acquisition and to learn how circumstantial factors can support a better learning.

\section{MATERIALS AND METHODS}

In order to fulfill the research aims established in the Background above, a multiple case study research design was conducted. It is to describe, analyze and interpret the facts in a study program of a 
higher education. And as this study involved multiple techniques such as interviews, observations, and surveys, both quantitative and qualitative research methods were applied.

This study involved 76 students and 4 lecturers in 4 Indonesian Language classes. Quantitatively, the data were collected through a survey to the respondents in which the student respondents filled out questionnaires provided, and interviews with the teaching staff as well as with the students. Qualitatively, data collection was carried out through classroom observations along with note-taking techniques.

\section{RESULTS AND DISCUSSION}

\subsection{Students Motivation to Learn Indonesian Language in GoBali, The University OF UDAYANA BALI}

As has been described above, student's motivation is one of the important factors in a foreign language learning process and many experts argue that the success of students is very dependent on the motivation they have. The survey results related to the motivation of foreign students in Indonesian language classes at Go Bali program in the Indonesian language classes is described as the following.

Why Bali? This is the first question asked to the students in the survey in order to identify their reasons of coming to Bali. The data analysis shows that 61.1 percent of the student respondents chose the option of to study and for holiday They explained that they chose Bali as the place to spend their summer holiday and taking a short course relating to their study is because the island is the best place to do so for its fame as a world tourist destination. In other words, they came to the island is not merely to study, but also for vacation and enjoying their holidays abroad As has been described in the introduction of this article, GoBali program actually designs its program in a way that balances study time and vacation (the fact is that there are only three compulsory days for the students to come and attend classes on campus). Hence, it can be understood that those who study in this program, of course, are mostly the ones who are interested in the study schedule. On the other hand, the analysis data also showed that as much as 33.3 percent of the respondents has intention only to study and learn about different cultures and surroundings and 5,5 percent chose the option of other reasons. The percentage is clearly seen in the following figure 1

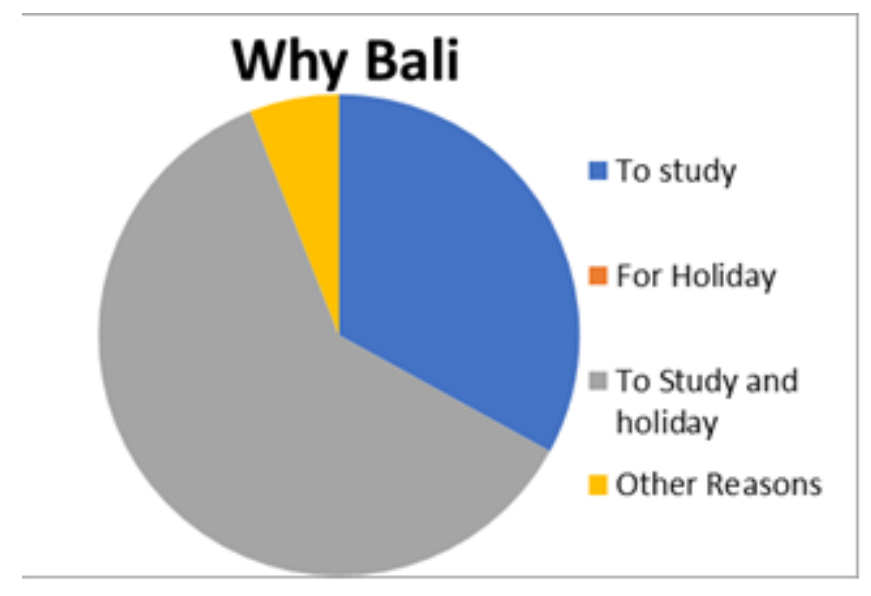

Figure 1. Student SurveyResult

Nowadays, Indonesian government is intensively promoting Indonesian language internationally and the important roles of foreign students in Indonesia to disseminate Indonesian language to all over the world is seen to be prospective. For this purpose, Indonesian language course becomes compulsory for all foreign students who study in Indonesia. From the analysis data, it shows that the above compulsion, then, had become the primary reason of most respondents $(55,5$ percent $)$ to include the subject into their course list. Meanwhile, the second option of to socialize with the locals was chosen by as much as 38.9 percent of the respondents regarding the reason why they studied Indonesian language, and only 5,6 percent agreed that by becoming skillful in the language will help them have a better future career. (Figure 2).

However, apart from the reasons, all of the student respondents (100 percent) actually agreed that, indeed, the ability to use the language in their communication with the locals would give them an easier life during their stay in Bali (Figure 3). I agree that Bahasa Indonesia is important while I am in Bali 
because it will help me to have a better communication with locals, and the good thing is it really helps us to do a better negotiation in prices when I do shopping. They furthermore commented that this is also one form of appreciation to their surroundings which will give positive impacts to their comfort and security in the island, and I think they are happy if we speak their language. Moreover, I believe it is a form of respect as well.

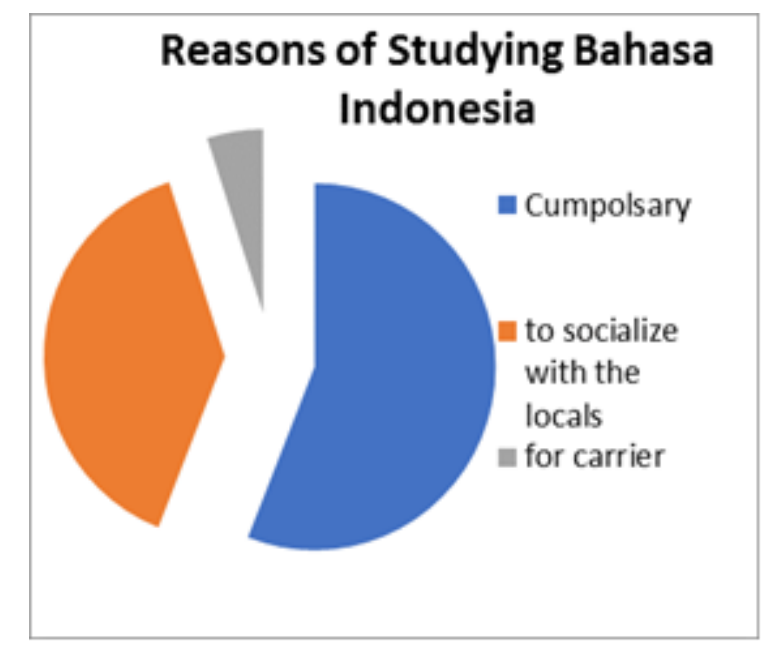

Figure 2. Reasons of Studying Bahasa Indonesia

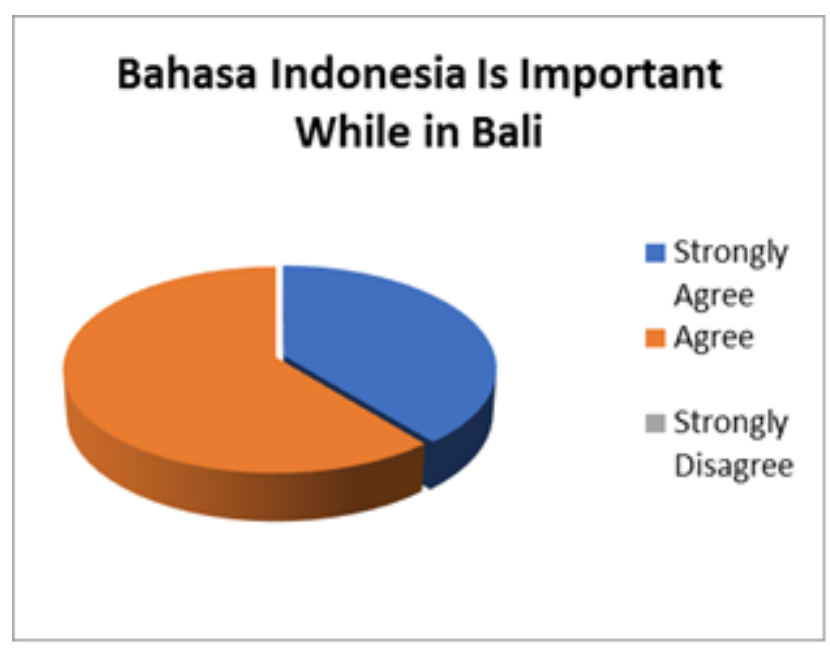

Figure 3. Bahasa Indonesia is Important while in Bali

When it comes to the last question of whether Indonesian language would be useful in supporting their career, as many as $88.9 \%$ of the total student respondents disagreed. They commented that even though it is good to know the language for themselves as an individual, but in business and many working places, they do not think that they would need it because English and other languages' skills are more important. In contrast, as illustrated in the figure (4) below, there are still some numbers of respondents (11.1 percent) believe that the skills of the language will give benefits to their lives. They added that being skillful in foreign languages, whatever they are, in fact, is a good thing and will give additional values to their journey in achieving the best in their career. 


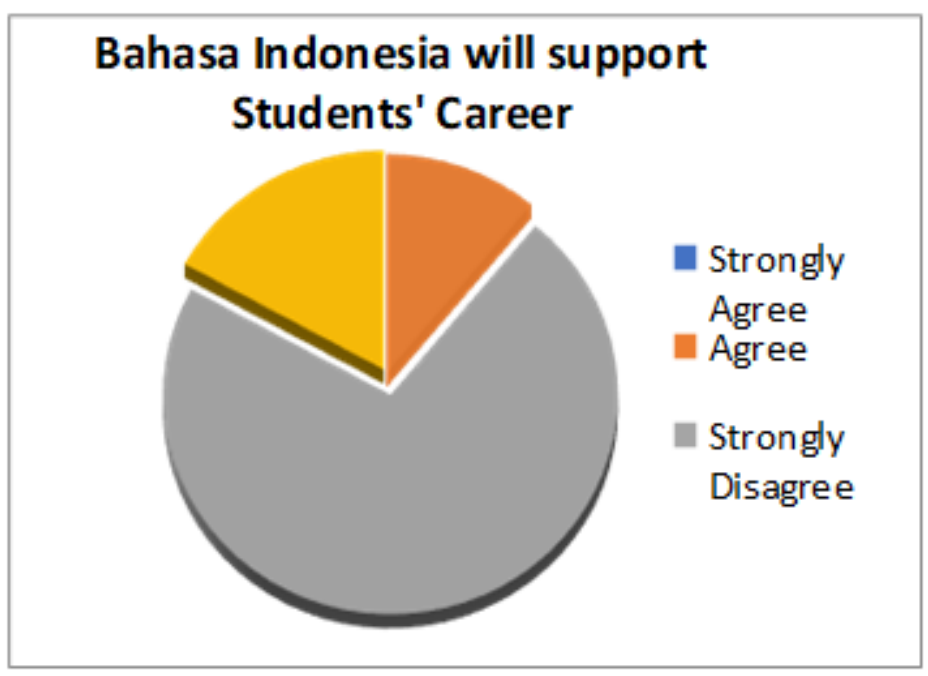

Figure 4. Bahasa Indonesia will support Students'Carrer

\subsection{Students' Motivation AND The EnVIRONMENT}

As described in the above sub-chapter, most student respondents stated that they came to Bali with the purpose of studying while on vacation. For their study, they chose Go Bali international study program at The University of Udayana because this program offers a learning system that balances their study and vacation time. The condition gives a special challenge for the lecturers of how to maintain and raise up the students learning motivation so that the course outcomes can be achieved.

Many researchers agree that learning environment which refers to psychological, social and the context where the learning occurs actually affects some aspects in the learning itself, including the students' learning motivation (Fraser\&Fisher, 1982; Ludtke, Robitzsch, Trautwein\&Kunter, 2009, in Ghrehasim, 2011). From the interviews with the student respondents it is found that most of the foreign students who study Indonesian language in Go Bali program, The University of Udayana are more motivated to learn Indonesian language, because the knowledge is beneficial for their communication with the locals during their stay in Indonesia. One of the student respondents commented, Eventhough I am not sure whether it will be beneficial for my career, but I think It is still good to be able to speak Bahasa Indonesia while I am in this country in which I can socialize more easily with the locals. It is also helpful if we want to learn about Indonesian culture, read sign so I won't get lost, hahaha, and when I do some shopping.

In order to maintain the motivation and raise it up, the lecturers managed their classrooms in such a way that is flexible to the needs of their foreign students. They commented that they do not rely too much on teaching Indonesian which must be in accordance with the formal language structure, but rather teach and introduce terms and vocabulary that would be useful for the students' daily communications with the locals. For that, the classes were set up mostly by applying teaching techniques which focus on communication activities to fulfill their students' requirements.

There was an interesting comment of a student respondent during the interview session (which was later agreed by two other respondents) that in fact they did not really agree with the need to be able to speak Indonesian while they were in Bali because as a tourism area the people who live on this island, of course, understand and can communicate in English. Frankly we don't really need to learn it because everybody we meet seem to understand and can communicate in English.

To respond to the comments the Indonesian language lecturers in an interview session argued that they were very aware of this condition and responded to it positively. We even direct the lessons in class to authentic materials, for example by inviting them to do role play activities with a topic Makan di Warung. In this activity students are introduced to various vocabularies and utterances which will be very useful when they want to eat and drink in a restaurant. This will increase their vocabularies of Indonesian food and beverages, and also learn numbers and money in Indonesian. We hope that by the application of several communicative techniques in a topic like this will make the class become more attractive and will help to increase my students' motivation to learn Indonesian because they get something that they need. We also hope that they will put more respect to our language, the people, this island and this country even more. 


\section{CONCLUSION}

From the analysis above it can be concluded that the learning motivation of the students in Indonesian language classes in Go Bali Program, The University of Udayana- Bali are varied and in general is relatively low. The purpose of most students coming to Bali and studying at the program is because this program designs their study which balances their vacation time. This can be understood because Bali is actually a very famous tourism area in the world and of course the students also want to enjoy Bali's tourist attraction. Regarding the Indonesian language course, as much as 55.5 percent respondents stated that they took this course because it was compulsory even though they all realized that Indonesian was very useful when they were on this island. But unfortunately, most of them (83.3\%) believe that their ability to speak Indonesian will not support their future careers.

Regarding the relationship between the environment where they study and their learning motivation, this study concludes that there is a close relationship between them. As they have the Indonesian language class in Bali where people speak Indonesian, they become more motivated to pick up the knowledge of the language in order to have a better communication with the locals.

\section{REFERENCES}

Bown, H. Douglass. 2007. Prinsip Pembelajaran dan Pengajaran Bahasa. USA Embassy: Pearson Education, Inc.

Ellis, Rod. 2006. Second Language Acquisition. New York. Oxford University Press.

Dörnyei, Z. 1994. Motivation and Motivating in the Foreign Language Classroom. The Modern Language Journal, Vol. 78, No. 3 (Autumn, 1994), pp. 273-284. Blackwell Publishing on behalf of the National Federation of Modern Language Teachers Associations

Dörnyei, Z., Csizér, K., \& Németh, N. (2006). Motivation, language attitudes, and globalization: A Hungarian perspective. Clevedon, UK: Multilingual Matters.

Gherasim, L. R; Simona, B; Iacob, L. 2011. The International Journal of Learning. USA: Champaign

Oroujlou, N. \& Vahedi, M. (2011). Motivation, attitude and language learning. Procedia Social and Behavioral Sciences, 29, $994-1000$.

Shinta, Q. Peran Motivasi Dalam Pembelajaran Bahasa Inngris. Jurusan Teknik Informatika STMIKPROVISI

(http://download.portalgaruda.org/article.php?article=266765\&val=6547\&title=Peran\%20Motivasi $\% 20$ Pada\%20Pembelajaran\%20Bahasa\%20Inggris). Retreived on 10 ${ }^{\text {th }}$ February 2018.

Wlodkowski, R. J. (1985). Enhancing adult motivation to learn. San Francisco: Jossey-Bass.

Ying, Y., Muhammad, N. S., \& Evi. A.H. Motivasi Belajar Bahasa Mandarin sebagai Bahasa Kedua. (https://www.coursehero.com/file/23181423/067-CHN-PSI-Yiying-Nanang-P-Evi-afifah/) Retrieved on $10^{\text {th }}$ February 2018.

Yusroh, M. (2016. Upaya Peningkatan Motivasi Belajar Bahasa Inggris pada Mahasiswa. Ibrahimy Genteng Banyuwangi. Darussalam: Jurnal Pendidikan, Komunikasi dan Pemikiran Hukum Islam Vol.VIII, No 1: 126-132. 
